\title{
Agar-Gel Precipitin-Inhibition Test for Coccidioidomycosis
}

\section{Preliminary Evaluation of the Complement-Fixation and Agar-Gel Precipitin Tests in the Serodiagnosis of Human Coccidioidomycosis}

\author{
JOHN G. RAY, JR. \\ Medical Sciences Laboratory, Fort Detrick, Frederick, Maryland 21701
}

Received for publication 10 February 1967

\begin{abstract}
The agar-gel precipitin-inhibition serological test for coccidioidomycosis was a more sensitive indicator of Coccidioides immitis antibodies than the tube precipitin, the agar-gel immunodiffusion, in the complement-fixation tests in assaying monkey sera, whether these sera were from prechallenge-vaccinated or postchallenged animals. When applying this technique to the assay of human sera, an analogous finding generally persisted. However, some human sera were positive by the complementfixation test and negative by the agar-gel precipitin-inhibition test. These sera were diffused in agar-gel against various coccidioidin complement-fixation, tube precipitin, and agar-gel precipitin-inhibition test antigens with essentially negative results.
\end{abstract}

In previous reports $(2,3)$, the agar-gel precipitin-inhibition (AGPI) and complement-fixation (CF) tests for coccidioidomycosis were compared for their ability to assay Coccidioides immitis antibodies in monkey and dog sera. In addition, the tube precipitin (TP) and the agar-gel immunodiffiusion (AGID) tests (1) were compared with the above serological tests in one set of experiments (2). The results indicate that the AGPI procedure was more sensitive than the CF, TP, or AGID tests in determining the $C$. immitis antibody content of these monkey sera, whether they were from prechallenged-vaccinated or postchallenged animals.

However, sufficient human serum specimens were not available at that time to perform an analogous assay. During the past year, a significant number of human coccidioidomycosis sera were obtained through the courtesy of Evelyn Wallraff, Veterans Administration Hospital, Tucson, Ariz., H. Gilbert Crecelius, Arizona State Department of Health, and John Bennett, National Institutes of Health Clinical Center. Comparative assays on these human sera are reported here.

\section{Materials AND Methods}

An agar-gel medium previously described by Ray and Kadull (4), a coccidioidin antigen prepared and supplied by John Converse, and a coccidioidomycosis antiserum, human or animal, of high CF titer $(1: 256$ or greater) were employed in the AGPI test. Standardization of the coccidioidomycosis AGPI test antigen- antibody system is attained by a box titration in agargel of serial dilutions of each reactant. This determines the minimal reacting dilution of test antigen and antibody that shows a visible precipitate in the agar-gel plates within $48 \mathrm{hr}$. Any inhibition of this test reaction by an unknown serum indicates the antibody titer of that serum. To obtain a visible reaction equidistant between the agar-gel wells, it is necessary to prediffuse the test antibody minimal reacting dilution, located in the center wells, $1 \mathrm{hr}$ at 23 to $27 \mathrm{C} \mathrm{(3)}$.

The CF titers in this report were attained by the source laboratory technique or by the Kolmer $100 \%$ fixation technique as used in our Fort Detrick Serology Laboratory. The latter technique utilized the recommended Communicable Disease Center CF antigen and human control antiserum.

The direct double diffusion tests of the CF positiveAGPI negative sera were performed in agar-gel plates having six wells equidistant from a center well (Fig. 1-3). The center wells contained the investigated sera, and the peripheral wells were charged with six different antigens. Each reagent was placed in its respective well every $24 \mathrm{hr}$ for 5 days. After the initial 5-day serial recharging with the reagents, the wells were recharged $24 \mathrm{hr}$ before the plate reactions were to be photographed. The incubation time was extended for 21 days at 23 to $27 \mathrm{C}$, and the reagents were not diluted for this series of tests. This treatment varied from the standard initial charging of reagents and observation periods of 48 to $72 \mathrm{hr}$ without further recharging in an effort to negate differences in concentration of the antigen or antibody content in these reagents.

\section{Results AND Discussion}

The AGPI procedure detected titers in prechallenged-vaccinated and postchallenged mon- 
TABLE 1. Comparison of serological results in monkey's response to cutaneous and pulmonary coccidioidomycosis

\begin{tabular}{|c|c|c|c|c|c|c|}
\hline \multirow{2}{*}{ Immunization } & \multirow{2}{*}{ Monkey } & \multicolumn{3}{|c|}{$\begin{array}{l}\text { Prechallenge reciprocal titer ( } 6 \text { months } \\
\text { postvaccination) }\end{array}$} & \multicolumn{2}{|c|}{$\begin{array}{l}15 \text { days postchallenge } \\
\left(\text { Silveira }^{a}\right) \text { reciprocal titer }\end{array}$} \\
\hline & & Skin test & $\mathrm{CF}$ & AGPI & CF & AGPI \\
\hline Unvaccinated (controls) & $\begin{array}{l}\text { T-40 } \\
\text { T-34 } \\
\text { T-74 } \\
\text { TR-74 } \\
\text { T-66 }\end{array}$ & $\begin{array}{l}- \\
- \\
- \\
-\end{array}$ & $\begin{array}{l}- \\
- \\
- \\
-\end{array}$ & $\begin{array}{l}- \\
- \\
- \\
-\end{array}$ & $\begin{array}{l}- \\
- \\
- \\
-\end{array}$ & $\begin{array}{l}- \\
- \\
- \\
-\end{array}$ \\
\hline $\begin{array}{l}\text { Viable vaccine } \text { (Silveira }^{a} \\
\text { spores) } \\
\text { Dose } 10\end{array}$ & $\begin{array}{l}\text { T-78 } \\
\text { S-22 } \\
\text { T-67 } \\
\text { T-44 }\end{array}$ & $\begin{array}{l}+ \\
+ \\
+ \\
+\end{array}$ & $\begin{array}{l}32 \\
- \\
-\end{array}$ & $\begin{array}{r}64 \\
8 \\
8 \\
4\end{array}$ & $\begin{array}{r}64 \\
8 \\
16 \\
8\end{array}$ & $\begin{array}{l}64 \\
64 \\
32 \\
32\end{array}$ \\
\hline Dose 100 & $\begin{array}{l}\text { T-38 } \\
\text { T-30 } \\
\text { T-77 } \\
\text { T-57 }\end{array}$ & $\begin{array}{l}+ \\
+ \\
+ \\
+\end{array}$ & $\begin{array}{l}16 \\
- \\
-\end{array}$ & $\begin{array}{r}32 \\
4 \\
2 \\
4\end{array}$ & $\begin{array}{r}32 \\
8 \\
- \\
8\end{array}$ & $\begin{array}{r}32 \\
16 \\
8 \\
16\end{array}$ \\
\hline Dose 1,000 & $\begin{array}{l}\text { T-63 } \\
\text { T-21 } \\
\text { T-17 } \\
\text { T-43 }\end{array}$ & $\begin{array}{l}+ \\
+ \\
+ \\
+\end{array}$ & $\begin{array}{c}\overline{16} \\
\overline{256}\end{array}$ & $\begin{array}{r}32 \\
64 \\
16 \\
512\end{array}$ & $\begin{array}{r}8 \\
16 \\
- \\
256\end{array}$ & $\begin{array}{r}32 \\
64 \\
32 \\
512\end{array}$ \\
\hline $\begin{array}{l}\text { Nonviable vaccine (Forma- } \\
\text { lin-killed Cash strain) }\end{array}$ & $\begin{array}{l}\text { S-38 } \\
\text { S-13 } \\
\text { TR-76 } \\
\text { TR-75 }\end{array}$ & $\begin{array}{l} \pm^{b} \\
\pm \\
\pm \\
\pm\end{array}$ & $\begin{array}{l}- \\
- \\
-\end{array}$ & $\begin{array}{l}- \\
- \\
-\end{array}$ & $\begin{array}{l}- \\
- \\
- \\
-\end{array}$ & $\begin{array}{r}8 \\
4 \\
2 \\
32\end{array}$ \\
\hline
\end{tabular}

${ }^{a}$ Refers to a strain of Coccidioides immitis.

${ }^{b}$ Questionable results (erythema but no induration).

TABLE 2. Comparison of postchallenge serological reactions in immunized and nonimmunized monkeys

\begin{tabular}{|c|c|c|c|c|c|c|c|c|c|c|c|c|c|c|c|c|c|}
\hline \multirow{3}{*}{$\underset{\text { agent }}{\text { Immunizing }}$} & \multirow{3}{*}{$\begin{array}{l}\text { Mon- } \\
\text { key }\end{array}$} & \multirow{3}{*}{$\begin{array}{l}\text { Disease } \\
\text { status }^{a}\end{array}$} & \multirow{2}{*}{\multicolumn{3}{|c|}{ Tube precipitin }} & \multirow{2}{*}{\multicolumn{3}{|c|}{ AGID }} & \multirow{2}{*}{\multicolumn{3}{|c|}{$\begin{array}{c}\text { Reciprocal titer } \\
\text { AGPI }\end{array}$}} & \multicolumn{6}{|c|}{ Complement fixation } \\
\hline & & & & & & & & & & & & \multicolumn{3}{|c|}{ Huppert } & \multicolumn{3}{|c|}{ Ray } \\
\hline & & & $2 \mathrm{wk}$ & $8 \mathrm{wk}$ & $12 \mathrm{wk}$ & $2 \mathrm{wk}$ & $8 \mathrm{wk}$ & $12 \mathrm{wk}$ & $2 \mathrm{wk}$ & $8 \mathrm{wk}$ & $12 \mathrm{wk}$ & $2 \mathrm{wk}$ & $8 \mathrm{wk}$ & $12 \mathrm{wk}$ & $2 \mathrm{wk}$ & $8 \mathrm{wk}$ & $12 \mathrm{wk}$ \\
\hline \multirow[t]{5}{*}{ Intact spherule } & $\mathrm{K}-21$ & $3+$ & 0 & 0 & 0 & \pm & + & + & 32 & 512 & 1,024 & 8 & 0 & 2 & 20 & 0 & 80 \\
\hline & $K-43$ & $2+$ & $\mathbf{0}$ & $\mathrm{NS}^{b}$ & + & $\overline{0}$ & + & + & 4 & 128 & 1,024 & 0 & 8 & 8 & NS & 160 & 640 \\
\hline & $\mathbf{K}-11$ & $1+$ & 0 & $\mathbf{0}$ & + & 0 & + & + & 4 & 128 & 256 & $\mathbf{0}$ & 8 & 4 & NS & 80 & 160 \\
\hline & K-20 & $2+$ & $\mathbf{0}$ & $\mathbf{0}$ & 0 & $\mathbf{0}$ & + & + & 0 & 128 & 1,024 & 0 & 0 & 0 & 0 & 0 & 0 \\
\hline & P-17 & $1+$ & 0 & 0 & 0 & 0 & + & + & 0 & 32 & 256 & 0 & $\mathrm{AC}^{c}$ & 128 & $\mathbf{0}$ & 80 & 640 \\
\hline \multirow{5}{*}{$\begin{array}{l}\text { Combined cell } \\
\text { fraction }\end{array}$} & S-49 & $2+$ & $\mathbf{0}$ & 0 & + & 0 & 0 & + & 0 & 8 & 4 & 0 & 0 & 0 & 0 & 0 & 0 \\
\hline & K-45 & $3+$ & 0 & 0 & + & 0 & + & + & 0 & 512 & 1,024 & 0 & 8 & 512 & $\mathbf{A C}$ & 80 & 1280 \\
\hline & P-12 & $2+$ & 0 & 0 & + & 0 & + & + & 0 & 256 & 1,024 & 0 & 16 & 256 & 0 & 640 & 640 \\
\hline & P-14 & $1+$ & 0 & 0 & + & 0 & + & + & 0 & 128 & 1,024 & 0 & 4 & 32 & o & 320 & 320 \\
\hline & P-15 & $2+$ & 0 & 0 & 0 & 0 & 0 & + & 0 & 16 & 8 & 0 & 0 & 2 & 0 & 10 & 10 \\
\hline
\end{tabular}

${ }^{a}$ Relative extent of infections: $1+$, mild; $2+$, moderate; $3+$, severe.

b No sample.

c Anticomplementary. 
TABLE 3. Comparative human coccidioidomycosis serum titrations

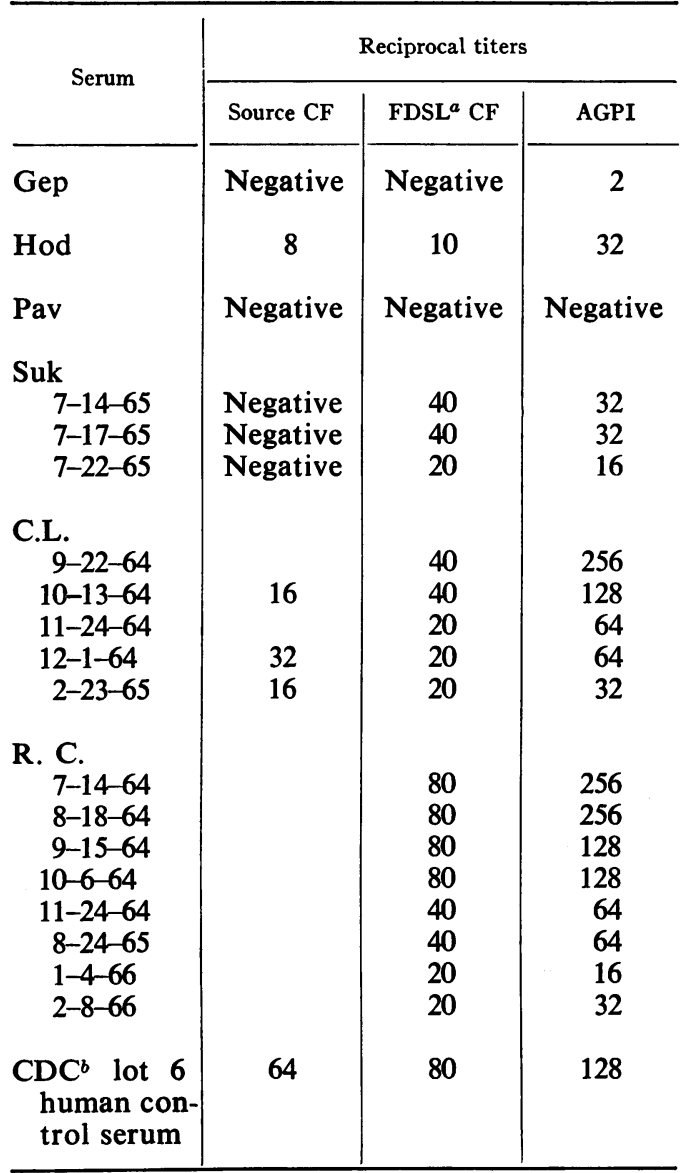

a Fort Detrick Serology Laboratory.

${ }^{b}$ Communicable Disease Center.

key sera when the CF tests were negative and permitted earlier titer evaluation; these titers generally persisted longer than those assayed by the CF technique (Table 1).

When the AGPI test results were compared with those of the CF, TP, and AGID tests in an interlaboratory investigation of sera from immunized and nonimmunized postchallenge monkeys, the AGPI test detected earlier titers in two of five sera in the spherule vaccine group and in two of five sera in the combined cell fraction group (Table 2).

In the combined cell fraction vaccine group, only the TP, AGID, and AGPI tests detected antibody response in the S-49 monkey serum; the $\mathrm{CF}$ tests were negative. Antibodies to $C$. immitis in the K-20 serum of the intact spherule vaccine group were detected only by the AGID and AGPI tests. It is also interesting to note in this vaccine group series that the Huppert CF test results in the 2-, 8-, and 12-week serum samples were either equivalent in titer or decreased; the AGPI test results, however, indicated a decided increase in titer over these same time periods. Although the reason for this is unknown, the possibility exists that the two laboratories may have measured different antigen-antibody reactions.

Human sera were also compared by the AGPI and $\mathrm{CF}$ techniques. The first samples titrated were those obtained from $E$. Wallraff and J. Bennett, and the titers were compared by the CF and AGPI test procedures (Table 3). The second group of human sera was obtained from $\mathbf{H}$. Gilbert Crecelius, and the titers were also compared by these test procedures (Table 4).

Three sera (17737, 17979, and 18961) having positive $L B C F$ titers $(1: 8,1: 4$, and $1: 32$, respectively) were negative by the AGPI test (Table 4). These findings are at variance with those obtained with monkey sera and could be caused by either differences in sera or differences in the antigens that assay their antibody content. Serum 17737 came from a patient with a positive skin test,

TABLE 4. Comparative human coccidioidomycosis sera titrations

\begin{tabular}{|c|c|c|c|}
\hline \multirow{2}{*}{ Serum } & \multicolumn{3}{|c|}{ Reciprocal titer ${ }^{a}$} \\
\hline & Source LBCF & FDSL CF & AGPI \\
\hline $\begin{array}{c}17202 \\
17204 \\
17206 \\
17338 \\
17729 \\
17730 \\
17731 \\
17737 \\
17843 \\
17848 \\
17973 \\
17979 \\
18113 \\
18184 \\
18185 \\
18799 \\
18961 \\
\text { CDC lot } 6 \\
\text { human } \\
\text { control } \\
\text { serum }\end{array}$ & $\begin{array}{r}16 \\
64 \\
64 \\
64 \\
32 \\
64 \\
128 \\
8 \\
8 \\
8 \\
16 \\
4 \\
8 \\
16 \\
8 \\
16 \\
32\end{array}$ & $\begin{array}{c}\text { Negative } \\
10 \\
80 \\
40 \\
10 \\
40 \\
40 \\
\text { Negative } \\
\text { Negative } \\
\text { Negative } \\
10 \\
\text { Negative } \\
5 \\
10 \\
5 \\
10 \\
\text { Negative }^{b}\end{array}$ & $\begin{array}{c}32 \\
128 \\
128 \\
128 \\
128 \\
128 \\
256 \\
\text { Negative } \\
32 \\
16 \\
16 \\
\text { Negative } \\
16 \\
16 \\
32 \\
64 \\
\text { Negative }\end{array}$ \\
\hline
\end{tabular}

${ }^{a}$ LBCF $=$ Laboratory Branch Complement Fixation test as proposed by the Laboratory Branch of the National Communicable Disease Center, Atlanta, Ga.; FDSL = Fort Detrick Serology Laboratory.

b Anticomplementary serum.

$c$ Communicable Disease Center. 


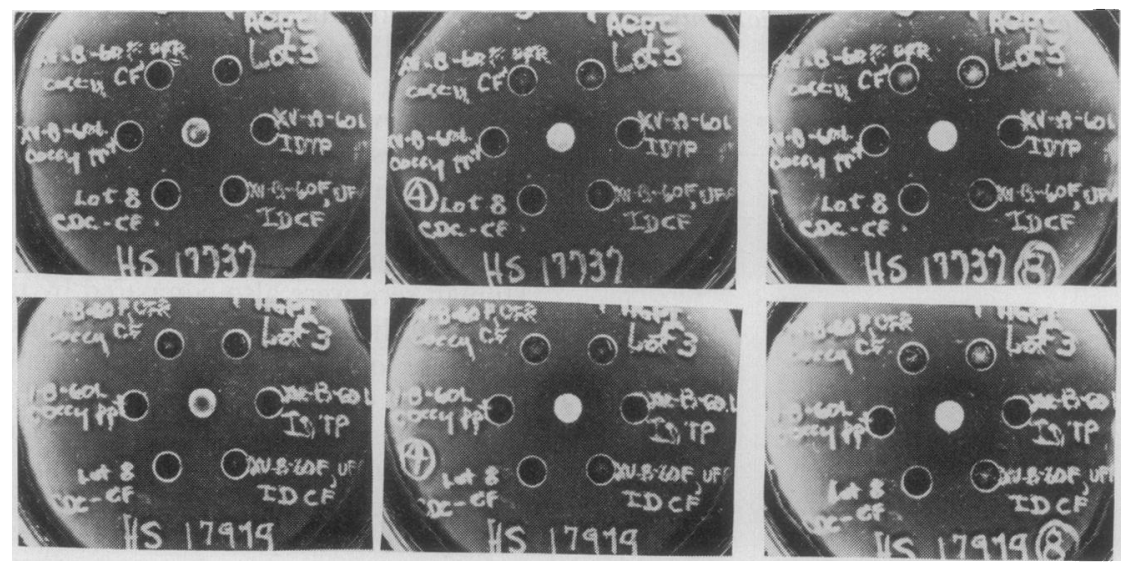
FIG. 1. Serial double diffusion of AGPI negative coccidioidomycosis human sera with selected CF, TP, AGID,
and AGPI test antigens.
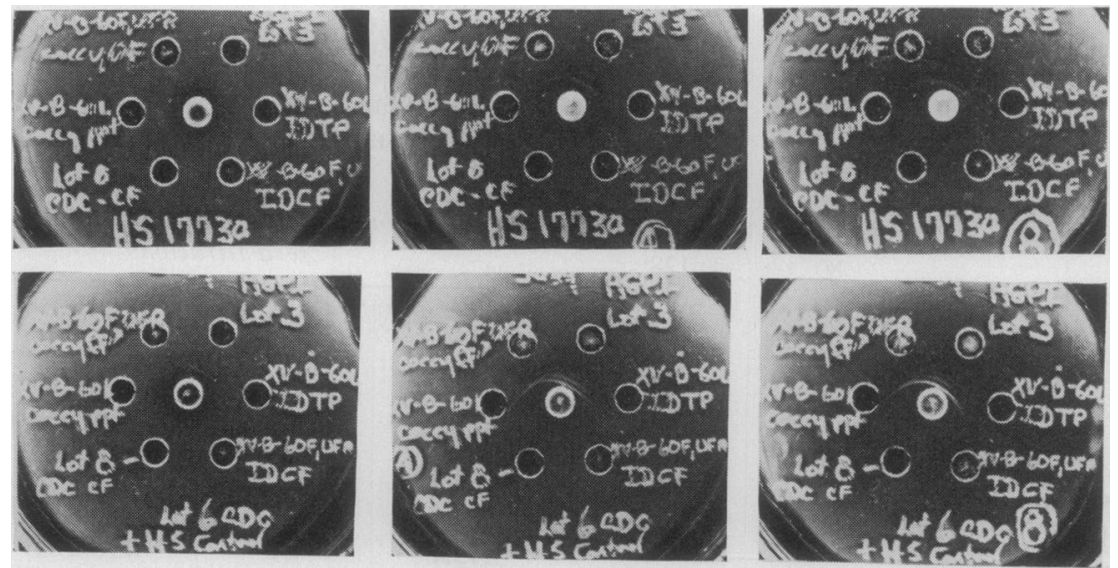
Fig. 2. Serial double diffusion of $A G P I$ positive coccidioidomycosis human sera with selected $C F, T P, A G I D$,
and $A G P I$ test antigens.
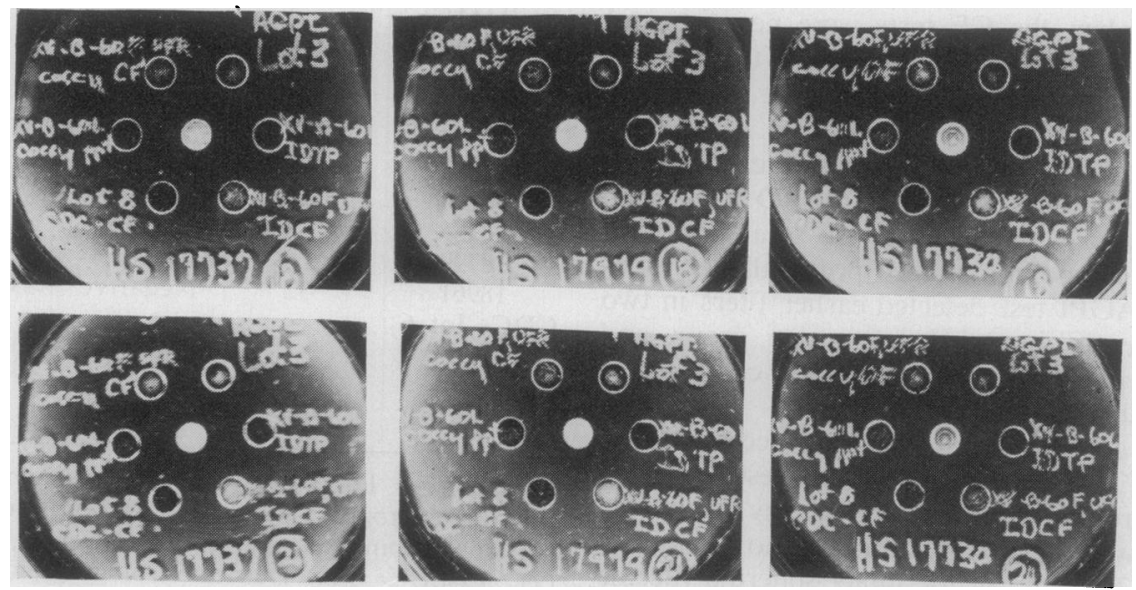

FIG. 3. Continued serial double diffusion of AGPI negative and positive coccidioidomycosis human sera with selected CF, TP, AGPI, and AGID test antigens. 
positive $\mathrm{X}$ ray, and positive culture of $C$. immitis from bronchial washings; serum 18961 came from a patient with a positive skin test, $X$ ray, and culture from animal inoculation; no case history was available on serum 17979.

Each of these sera was diffused in agar-gel against six antigen preparations. $M$. Huppert supplied four antigens: the XV-B-60F, UFR coccidioidomycosis $\mathrm{CF}$ antigen, the $\mathrm{XV}-\mathrm{B}-60 \mathrm{~L}$ coccidioidomycosis precipitin antigen, the XV-B60L IDTP antigen, and the XV-B-60F, UFR IDCF antigen. In addition, lot 8 CF antigen was obtained from the Communicable Disease Center, and lot 3 coccidioidin was obtained from John Converse. These six antigens were employed in the agar-gel double diffusion of the above sera as well as of a positive control serum, 17730 from H. G. Crecelius' laboratory, and lot 6 Communicable Disease Center human positive $C F$ control serum. Each reagent was placed in its respective well every $24 \mathrm{hr}$ for 5 days. After the initial 5-day serial recharging with the reagents in their wells, the wells were recharged $24 \mathrm{hr}$ before the plate reactions were to be photographed. This treatment tends to negate differences in concentration of the antigen or antibody content in these reagents.

Figure 1 depicts the serial diffusion of the reagents and shows that no activity was detected from sera 17979 and 17737 (both negative by the AGPI technique and positive by the LBCF method).

Figure 2 shows that the positive control serum 17730 and lot 6 Communicable Disease Center CF human serum control were both positive, to varying degrees, with the diffused antigens.

After continuing this procedure for 18 and 21 days (Fig. 3), a weak antigen-antibody reaction appeared between the two sera, 17737 and 17979, and lot 3 AGPI and XV-B-60F (UFR coccidioidomycosis (F) antigens. To determine the significance of this measured antigen-antibody reaction would require a coccidiodomycotic test antigenantibody evaluation.
This present experiment, however, shows that these antigens in the standard test concentrations would not give an antibody titer of coccidioidomycosis with these negative sera, either by inhibition of the antigen in the AGPI test or by binding of complement in the CF test. Similarly, AGID antigens would not have detected the presence of coccidioidomycosis antibodies in these sera, because a larger total concentration was employed in both reagent wells and a longer observation period was used. However, certain CF test antigens did measure an apparently different antibody content in suspect coccidioidomycotic sera as a result of differences in antigenic content. This observation requires further investigation.

\section{ACKNOWLEDGMENTS}

We acknowledge the technical assistance of Maurice M. Mount, Jr., and Mildred A. Volpe.

Tables 1 and 2 are taken from Coccidioidomycosis: Pertinent Findings and Developments, Arizona State Department of Health, University of Arizona Press, 1967.

\section{Literature Cited}

1. Huppert, M., and J. W. Bailey. 1963. Immunodiffusion as a screening test for coccidioidomycosis serology. Sabouraudia 2:284-291.

2. LoWe, E. P., T. J. SinSKI, M. HupPert, AND J. G. RAY, JR. 1967. Coccidioidin skin tests and serologic reactions in immunized and infected monkeys, p. 171-174. In L. Ajello [ed.], Coccidioidomycosis: Pertinent findings and developments. Arizona State Department of Health. University of Arizona Press, Phoenix.

3. RAY, J. G., JR. 1967. Serum titration of human and animal coccidioidomycosis by agar-gel precipitin-inhibition, p. 215-220. In L. Ajello [ed.], Coccidioidomycosis: Pertinent findings and developments. Arizona State Department of Health. University of Arizona Press, Phoenix.

4. RAY, J. G., JR., AND P. J. KadULl, 1964. Agar-gel precipitin technique in anthrax antibody determination. Appl. Microbiol. 12:349-354. 